\title{
Diet as a Potential Moderator for Genome Stability and Immune Response in Pediatric Leukemia
}

\author{
Shanshan Wang ${ }^{1}$, Christopher A. Maxwell ${ }^{1,2, *(\mathbb{D})}$ and Neha M. Akella ${ }^{1, *(D)}$ \\ 1 Department of Pediatrics, Faculty of Medicine, University of British Columbia, Vancouver, BC V6H 3V4, Canada; \\ shanshan.wang@bcchr.ca \\ 2 Michael Cuccione Childhood Cancer Research Program, BC Children's Hospital, Vancouver, BC V5Z 4H4, Canada \\ * Correspondence: cmaxwell@bcchr.ubc.ca (C.A.M.); neha.akella@bcchr.ca (N.M.A.)
}

check for

updates

Citation: Wang, S.; Maxwell, C.A.; Akella, N.M. Diet as a Potential Moderator for Genome Stability and Immune Response in Pediatric Leukemia. Cancers 2021, 13, 413. https://doi.org/10.3390/cancers 13030413

Received: 8 January 2021

Accepted: 18 January 2021

Published: 22 January 2021

Publisher's Note: MDPI stays neutral with regard to jurisdictional claims in published maps and institutional affiliations.

Copyright: (c) 2021 by the authors. Licensee MDPI, Basel, Switzerland. This article is an open access article distributed under the terms and conditions of the Creative Commons Attribution (CC BY) license (https:// creativecommons.org/licenses/by/ $4.0 /)$.
Simple Summary: Pediatric acute lymphoblastic leukemia (ALL) is the most prevalent cancer affecting children in developed societies. Here, we review the role of diet in control of the incidence and progression of childhood ALL. Prenatally, ALL risk is associated with higher birthweights of newborns, suggesting that ALL begins to evolve in-utero. Indeed, maternal diet influences the fetal genome and immune development. Postnatally, breastfeeding associates with decreased risk of ALL development. Finally, for the ALL-affected child, certain dietary regimens that impact the hormonal environment may impede disease progression. Improved understanding of the dietary regulation of hormones and immunity may inform better approaches to predict, protect, and ultimately save children afflicted with pediatric leukemia.

Abstract: Pediatric leukemias are the most prevalent cancers affecting children in developed societies, with childhood acute lymphoblastic leukemia (ALL) being the most common subtype. As diet is a likely modulator of many diseases, this review focuses on the potential for diet to influence the incidence and progression of childhood ALL. In particular, the potential effect of diets on genome stability and immunity during the prenatal and postnatal stages of early childhood development are discussed. Maternal diet plays an integral role in shaping the bodily composition of the newborn, and thus may influence fetal genome stability and immune system development. Indeed, higher birth weights of newborns are associated with increased risk of ALL, which suggests in-utero biology may shape the evolution of preleukemic clones. Postnatally, the ingestion of maternal breastmilk both nourishes the infant, and provides essential components that strengthen and educate the developing immune system. Consistently, breast-feeding associates with decreased risk of ALL development. For children already suffering from ALL, certain dietary regimens have been proposed. These regimens, which have been validated in both animals and humans, alter the internal hormonal environment. Thus, hormonal regulation by diet may shape childhood metabolism and immunity in a manner that is detrimental to the evolution or expansion of preleukemic and leukemic ALL clones.

Keywords: diet; pediatric leukemia; genome; immune response

\section{Introduction}

Diet and nutrition are the most critical determinants of human cancer risk [1]. In 1981, a landmark report estimated that one-third of cancers are attributable to diet [2]. Since that time, many investigations have linked improper nutrition with the process of tumorigenesis, including epidemiology observations, clinical trials, animal research, molecular mechanism studies, and genetic and epigenetic research [3-5]. Unsurprisingly, these associations also exist in childhood tissues.

Pediatric leukemias are blood cancers arising in children that involve the abnormal development of leukocytes, which then excessively accumulate in the bone marrow and blood and cause a host of pathologies. The most common leukemias in children are 
acute lymphoblastic leukemia (ALL), acute myeloid leukemia (AML), chronic lymphocytic leukemia (CLL), and chronic myeloid leukemia (CML). The incidence for each of these diseases is quite low, but pediatric ALL is by far the most prevalent, making up approximately $75 \%$ of all childhood leukemia patients [6]. Indeed, pediatric ALL is a leading cause of non-accidental deaths among children in developed countries [7]. Fortunately, patients suffering from pediatric leukemia have high cure rates. However, the incidence of the disease has been consistently increasing, and it is proposed that a combination of prenatal and postnatal factors contribute to this increasing risk [8]. This review will discuss the associations between diet and nutrition with childhood leukemia risk and prognosis, the maintenance of genome stability, the generation of immune responses, and the management or surveillance of preleukemic and leukemic clones.

\section{Associations between Nutrition and the Development of Childhood Leukemia}

Some childhood cancers have embryonic or pre-natal origins. In B-cell acute lymphoblastic leukemia (B-ALL), for example, pre-cancerous embryonic cells exist prenatally, and their survival and ability to initiate tumorigenesis depend on genetic events and acquisition of mutational load [9]. Primitive fetal hematopoiesis begins in the yolk sac, followed by definitive hematopoiesis (fetal and adult lineages) in the aorta-gonad-mesonephros region [10], before localizing to the fetal liver prenatally and bone marrow postnatally [11]. The first oncogenic event leading to partial transformation in-utero is proposed to occur as development progresses through these stages [11]. Transformation and cell susceptibility are attributed to developmental errors, cell-intrinsic factors, and cell-extrinsic factors in the environment, including maternal regulation of fetal development [11]. The fetus is affected by subtle changes in maternal nutrition with effects that carry over to adult life. Thus, maternal health is crucial to fetal development and the regulation of developmental origins of disease and disease predisposition [12].

The connections between diet and disease are extremely complex, and variations in study designs and research subjects may explain conflicting associations. However, some dietary associations with risk of developing childhood leukemia are now well-defined, including a balanced maternal diet. Regular consumption of vegetables and fruits/fruit juices by mothers during pregnancy $[13,14]$ and by children up to the age of two, could reduce the risk of leukemia development between 2 and 14 years of age [15]. In a study on the Han Chinese population, a diet rich in bean curds and vegetables was protective, whereas cured/smoked meat was associated with increased risk [16]. A similar increase in risk was associated with a maternal diet rich in sugars, syrups, and meats, and a decreased risk with consumption of vegetables, fruits, legumes, and seafood $[13,17,18]$. Surprisingly, these associations can be made with diet quality up to a year before pregnancy. That is, an overall healthy diet in women prior to pregnancy could lower the risk of leukemia in offspring; there is a stronger association with children diagnosed before the age of five [19].

Folate supplementation and low maternal intake of alcohol and caffeine are also associated with lower risk for childhood leukemia. Adequate folic acid and other micronutrient supplementation during pregnancy is associated with lower risk of childhood leukemia, over various populations and backgrounds, possibly through epigenetic modifications that drive oncogenesis $[17,20,21]$. Conversely, maternal alcohol intake both during and prior to pregnancy can increase the risk of childhood leukemia, and the risk increases even further with increased frequency of alcohol intake [22,23]. A comprehensive analysis that combined reports from multiple case studies reported a potential adverse effect of consuming more than a cup of coffee a day in a dose response manner during pregnancy [24]. Previous meta-analysis of over 3500 cases, observed a correlation between childhood leukemia and high coffee and any cola consumption in pregnant mothers, and inversely, a protective effect of tea consumption [25]. No such associations with tea consumption were made in the more recent analysis [24]. Although the analysis did not go into specifics of causation, it alluded to probable mechanisms from previous studies-caffeine has been known to cause inhibition of ATM kinase [26], tumor suppressor p53 [27], and DNA topoisomerase II [28], 
all of which play roles in leukemia [24]. Topoisomerase II inhibition through maternal dietary sources in close to 100 mothers was significantly associated with increased AML risk in infants with a mixed lineage leukemia (MLL) gene translocation [29]. Although the associations with alcohol, caffeine, and smoking are most frequently observed in childhood ALL, they are also seen in other types of childhood leukemia, lymphoma, Wilms' tumor, and brain cancer with transplacental exposures to these factors [30].

Breastfeeding has been promoted for its protective health benefits, access, and low-cost impact. Multiple studies measured childhood leukemia outcome in response to breastfeeding exposure, summarized in a meta-analysis by Amitay and Keinan-Boker [31]. Using stringent selection criteria to narrow down on high quality studies, 17 different case studies conducted between 1960 and 2014 were analyzed. Breastfeeding for more than 6 months was found to be protective and decreased risk of leukemia by $20 \%$, and breastfeeding ever compared to no breastfeeding at all was enough to lower risk by $9 \%$ [31]. Breastmilk is rich in maternal antibodies, maternal cells (breast-derived early-stage stem/progenitor cells and blood-derived immune and hematopoietic cells), anti-inflammatory molecules, and enzymes [32]. Maternal cells and signaling molecules in breastmilk have been found to survive long term in the offspring, enabling them to reach various organs and tissues and imparting immunity and a healthy gut microbiome to infants, thereby offering protection against diseases. Breastmilk constituents are known to modulate immune regulation, tolerance, tissue-repair, and overall infant development [32,33]. Thus, it would be fair to hypothesize that breastmilk also impacts disease susceptibility, especially in a disease of the immune system, such as leukemia. Indeed, a recent metabolomics analysis on neonatal blood spots found that patients that went on to develop early (ages 1-5) and late (ages 6-14) leukemia, had distinct metabolomic profiles [34]. The study revealed that the presence of certain fatty acids, several of which were related to breastmilk, breastfeeding duration (reduced risk), and maternal body mass index (BMI) (increased risk), could influence risk of early and late leukemia incidence [34].

It is also worth considering environmental exposures to chemicals indirectly through food consumption or packaging, such as pesticides, solvents, and other pollutants [35]. A meta-analysis by Heindel et.al. [36] summarizes 425 epidemiological studies between 1988 to 2014 that report disease outcomes correlated with exposure to environmental pollutants. The most common exposures were to industrial chemical polychlorinated biphenyls, organochlorine pesticides, mercury, and lead [36]. Health outcomes of neurological deficits and cancer were among the highest. Interestingly, most of the reported exposures occur in-utero and/or during early development. Fetal exposure to chemicals has been linked to leukemia diagnosis outcomes in infancy and childhood [36]. While associations with maternal exposures are more frequently reported, there is also an association between paternal occupational exposure to pesticides and other industrial solvents to increased childhood cancer risk [37]. In addition to chemical exposures, exposure to low dose radiation has potential long-term health effects. Nuclear workers exposed to low dose radiation over a long period of time, children exposed to natural background radiation in-utero and infancy, and those exposed to medical imaging technology, all point to some degree of association with increased cancer incidence [38-40]. In fact, leukemia was the most frequently reported cancer among the survivors of the atomic bomb, with a much higher risk in children under the age of 10 [41]. This is not surprising, given that bone marrow is highly sensitive to ionizing radiation, which then causes damage to hematopoietic stem cells [42]. Finally, other environmental cues such as stress can also induce epigenetic modifications in-utero that are responsible for development of adult health defects and disease [43].

Adult and childhood cancers are frequently characterized as genetic diseases. While the connection between genetic mutations and cancer is unquestionable, it is equally clear that the expression and consequences of harmful or pathogenic mutations can exist on a continuum that can be modified and overseen by the tumor or tissue microenvironment. Additionally, while genetic mutations may be heritable and hard-wired, the tumor or tissue microenvironment is likely to be more pliable and responsive to exogenous factors, such as 
diet and nutrition. It is, therefore, worthwhile to closely examine the impact of nutrition on childhood leukemia development (Figure 1) and prognosis.

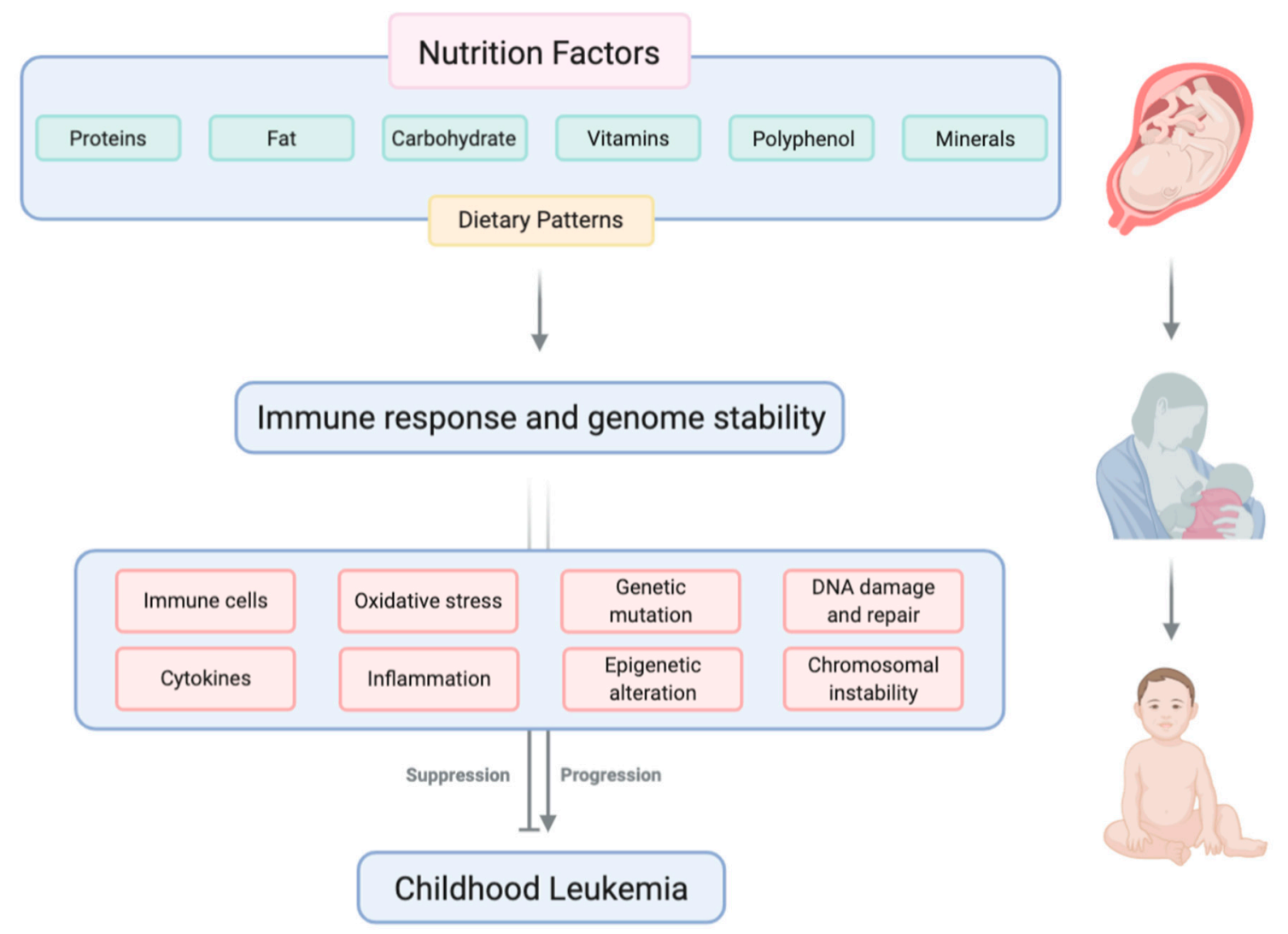

Figure 1. Nutritional factors, including macronutrients and micronutrients, can influence the development of childhood leukemia by modulating immune response and genome stability. Created with BioRender.com.

\section{Nutrition and the Prognosis or Treatment of Childhood Leukemia}

Inadequate nutrition, often due to socio-economic forces, can increase predisposition to diseases, and / or reduce survival in pediatric cancer patients. For example, malnourished patients at diagnosis had poor prognosis and overall survival rates to treatment, which worsened with time [44]. In a 2017 study in Nicaragua, about 70\% of patients of ages 6 months to 18 years were malnourished with increased treatment-related morbidity and reduced event-free survival [45]. In addition, malnutrition reduced patient immunity and increased susceptibility to infections, thereby affecting treatment response and mortality [46]. Not only is malnutrition a poor prognostic factor for leukemia, but it is also a common side-effect in pediatric patients undergoing cancer treatment. Treatment-induced malnutrition can differ among pediatric patients, with some patients suffering malnutrition during treatment, but a few patients are at a higher risk of gaining weight [47]. While malnutrition is often observed in children living in low-income and middle-income countries, obesity is prevalent in high-income countries; both malnutrition and obesity are associated with poor prognosis [48].

Obesity and being overweight are among the five global risks for increased cancer incidence in the world [49]. Patient diet and nutrient intake seem to vary significantly over the course of cancer treatment, leading to changes in BMI and potentially leading to an obesogenic effect [50]. In fact, fetal embryo cord blood from obese mothers had different gene expression profiles, including changes in immune and inflammatory signaling, compared to controls [51]. In a population of about 5000 ALL patients between the ages of 2 and 20, obesity before treatment was identified to associate with high risk B-ALL, in Hispanic and male populations more than others [52]. These associations also hold in some animal 
models of ALL. For instance, obese mouse models of ALL displayed increased levels of insulin, leptin, and inflammatory cytokines, leading to increased oxidative stress [53].

Overnutrition or undernutrition, in addition to already varied diets among patients, can cause large fluctuations in BMI and thus in drug response [50]. It is therefore critical to develop specific nutritional plans and interventions that address toxic effects and identify essential supplementation during treatment. The European Society for Clinical Nutrition and Metabolism and the Spanish Society of Medical Oncology guidelines are two examples of nutrition recommendations developed for cancer patients. These include pre-treatment screenings; strategies for nutrition and physical activity, specialized for treatment type and stage of disease; and finally, recommendations for cancer survivors who are at higher risk for additional health conditions, especially obesity and relapse after treatment [54-56].

Nutrient supplementation may improve treatment outcomes for childhood leukemia. For example, glutamine supplementation was performed in ALL patients with low to moderate disease undergoing chemotherapy over four weeks [57]. Physical, biochemical, and immunological indicators were observed, and the addition of glutamine to diet improved nutritional status and reduced edema in the treatment group [57]. The overall amounts of T-cell subsets and natural killer cells significantly decreased after chemotherapy, and glutamine-fed patients had improved numbers, pointing to improved immune function [57]. Along the same lines but in an acute leukemia mouse model, two strains of lactobacillus were supplemented in diet to enhance immunity [58]. The mouse model showed loss of gut microbiome components, and reintroduction of lactobacillus reduced inflammatory cytokine production and muscle atrophy markers. However, this effect was not seen when supplemented with other strains of lactobacillus [58].

Retrospective analysis of dietary intake has also revealed associations between diet and treatment outcomes. In a dietary intake study that evaluated over 500 patients undergoing treatment, bacterial infections were found to be reduced in patients who consumed more B-carotene and vitamin A through diet [59]. Additionally, vitamins A and E, and zinc from dietary sources and B-carotene supplementation reduced the incidence of mucositis. Interestingly, patients on supplements below dietary recommended intakes had increased rates of bacterial infections and mucositis during post-induction treatment [59]. Another study observed vitamin D deficiencies associated with decreased survival and poor outcome in childhood leukemia patients in India, most of whom were deficient before treatment and some after chemotherapy [60]. Mortality during treatment induction, commonly related to infections, was high in vitamin D-deficient patients [60]. A limited small-scale study of less than 25 patients showed increased cellular oxidative stress associated with high protein consumption [61]. Correspondingly, a low protein diet in mouse models of lymphoma was able to slow tumor growth [62]. However, the majority of studies still point to benefits of proteins from good sources, such as legumes and vegetables as mentioned earlier, because childhood leukemia treatments often lead to protein malnutrition.

Proper nutrition impacts how a patient responds to treatment and should be factored in when formulating a treatment and long-term follow-up plan. In the near term, it is important to perform comprehensive screenings, and closely monitor and modify food intake of patients throughout treatment. Nutrient supplementation, for example, may modulate responses and lower treatment associated morbidities. It is clear that diet and nutrition have the potential to positively impact leukemia patients' outcomes.

\section{Micronutrients and Macronutrients Control Genome Stability}

Foodstuffs are composed of both micronutrients and macronutrients. Micronutrients are vital in the normal functioning of life, with many acting as substrates or cofactors for enzymes responsible for genome maintenance and repair. Moderate deficiency results in genomic damage equivalent to damage caused by exposure to sizeable doses of genotoxins, such as chemical carcinogens and radiation [63]. At the cellular level, micronutrient excesses or deficiencies may lead to micronuclei formation, DNA oxidation and chromosome damage, and loss of DNA transcription fidelity, and are likely significant contributors to 
transformation [64-66]. It is prudent to highlight a few specific examples. Iron deficiency is the most common micronutrient deficiency in children worldwide. Daily iron supplementation, up to two-fold of the dietary recommended intake, can prevent micronuclei formation and enhance genome stability [67]. Iron has been recognized as an essential component of fundamental cell cycle progression [68]. Iron status variation can influence DNA metabolism functions by affecting multiple enzymes required for DNA synthesis and repair $[68,69]$. A recent study showed that human family B DNA polymerases required iron as a cofactor to maintain the enzyme's function and stability to influence the fidelity of DNA synthesis [70]. However, overload of iron has also been linked to genome instability and increased cancer risk [71]. Excessive iron compounds can induce genotoxicity by increasing the mutagenic response in mouse lymphoma assays. Overdose of iron has been reported to induce double strand breaks in mouse models [72]. Thus, it is essential to elucidate the appropriate dosage of iron supplement to improve health and nutrition balance without the toxic effects.

Calcium, another essential mineral for life, is necessary for multiple biological functions, including building healthy bones, muscles, and nerves, and maintaining the fundamental cell progressions [73]. However, exposure to high calcium concentration may induce genome instability. In an Australian study, hypercalcemia has been related to the formation of shorter telomeres [74]. Hypercalcemia can also increase chromosomal damage and is linked to the incidence of childhood leukemia [75]; moreover, high plasma calcium was positively correlated with micronuclei formation in a cross-sectional study involving 462 children [76]. Similar results are reported for high intakes of magnesium and zinc and micronucleus frequency [77]. Zinc, an essential component of over 300 enzymes [78], is critical to the control of cellular growth and genome stability $[79,80]$. An in vitro study found that zinc deficiency or excess was tightly related to increased DNA damage and chromosome instability in human lymphocytes [81]. Micronuclei frequency and apoptotic and necrotic percentages were significantly increased in zinc deficient and zinc-oversupplied cultures [81]. Excesses in aluminum or copper can also prompt the accumulation of DNA damage [82,83]. However, another study by Fenech et al. [84] found that supplementing with vitamin E, calcium, folate, retinol, and nicotinic acid was associated in each case with a significant decrease in genomic damage, as indicated by reduced micronuclei frequency; this study also correlated an increase in micronuclei formation with high intakes of certain micronutrients, including riboflavin, pantothenic acid, and biotin. Thus, micronutrient intake is an essential requirement for the maintenance of genome stability and must be carefully regulated and controlled.

Macronutrients include dietary protein, fat, and carbohydrates, and all are indispensable in the regulation of normal physiology. Dietary protein provides amino acids, some of which the body cannot produce on its own, as a foundation upon which all other protein molecules in the body are formed. Soybeans are a critical dietary protein source in many countries. Dietary soy protein can decrease circulating insulin levels and prevent insulin-induced DNA damage [85]. Conversely, excessive protein intake, like a high casein diet, may induce DNA damage, which can be abolished by dietary-resistant starch [86]. In pediatric leukemia patients, protein consumption is thought to alter intracellular oxidative stress, and as a consequence, influence chemotherapeutic efficacy [61].

Dietary fat provides glycerides and fatty acids that are important for regulating energy storage and body temperature. Dietary fat is mainly derived from animal fats and plant fats, consisting predominantly of saturated fats and unsaturated fats, respectively [87]. In an in vitro study that treated human aortic endothelial cells with omega-3 fatty acid, researchers found supplementation with polyunsaturated omega-3 fatty acids can attenuate oxidative stress-induced DNA damage, including abasic sites, oxidized bases, and strands breaks [88]. Conversely, a high fat diet may result in DNA damage by increasing hydrogen peroxide, superoxide production, and expression of oxidative stress response genes $[89,90]$. In a recent prospective cohort study, children born to mothers with high BMIs were at high 
risk of developing leukemia [91]. A similar association of increased leukemia in overweight mothers was found in a retrospective case-control study in California [92].

Nutrition status is likely to intersect the balance between genome stability and pediatric leukemia initiation, progression, and treatment. These complex interconnections are being dissected through emerging nutrigenomics analyses, which aim to decipher nutrient-gene-cancer networks. Briefly, Table 1 outlines recent nutrigenomic studies in the field of pediatric leukemia. 
Table 1. Overview of recent nutrigenomic studies in the field of pediatric leukemia.

\section{Author}

Objective
Investigate the potential mediating mechanism between environment and pediatric ALL disease risk.
Methods

Timms et al., 2019 [93]

vestigate the relationship

between maternal genotypes in

folate-related genes and pediatric ALL.

Schraw et al., 2018 [94]

dentify the relative contribution of gene-environment interactions to pediatric ALL.
Epigenome-wide association study (EWAS) $(\mathrm{n}=861-927)$

\section{Results}

- DNA methylation may play an intermediary role in the causal pathway linking childhood ALL risk exposures with disease risk

- Hypergeometric probability tests demonstrate directionally concordant gene methylation changes observed in ALL disease and in response to alcohol intake $(p=0.006)$; sugary caffeinated drink intake during pregnancy $(p=0.045)$.

Genome-wide DNA methylation profiling and single nucleotide polymorphism election and genotyping method. (sample from 51 pediatric ALL patient-mother pairs er pair and 6 healthy donors)

Using genome-wide genotyping to investigate gene-environment interaction.

358 childhood ALL cases and 1192 population controls)
- Maternal folate metabolism may impact leukemogenesis via DNA methylation. - Differential DNA hypermethylation in patients with ALL according to maternal MTR genotype

- Maternal MTR rs12759827 may influence DNA hypermethylation in ALL.

- $\quad$ IKZF1 and ARID5B variants are associated with childhood ALL in an Australian Caucasian population

- $\quad$ IKZF1 variant is a genetic effect if the mother took folic acid or drank alcohol.
Identify associations between pre-therapeutic BMI and outcome in pediatric AML.
Multinational study of 867 pediatric AML patients diagnosed within the last

$$
\text { two decades. }
$$

Pyrosequencing to confirm the target hypermethylation genes; identify

Investigate the relationship between maternal folate and related B-vitamin intake during pregnancy and pediatric ALL risk. to folate depletion and in ALL. directional methylation change in response
- Obesity is associated with developing leukemic cytogenetic abnormalities

- $\quad$ Pediatric AML cytogenetics appear to differ by BMI status.

- $\quad$ BMI standard deviation score associated with frequency of inv(16)/t $(16 ; 16)$ and $t(8 ; 21)$

- $\quad$ Hypermethylation of ASCL2, KCNA1, SH3GL3, SRD5A2 in ALL is confirmed by measuring 20 patient samples.

- $\quad$ SH3GL3 methylation is inversely related to maternal red blood cell folate concentrations.

- ASCL2 methylation is inversely related to infant vitamin B12 levels.
Confirm maternal consumption of dietary DNAt2 inhibitors during pregnancy would increase the risk of infant leukemia.
Case-control study $(240$ cases of infant acute leukemia and 255 random digit dialed controls)
- Fresh vegetables and fruits consumption during pregnancy may decrease the risk of infant leukemia, particularly MLL+.

- Maternal consumption of dietary DNAt2 inhibitors (fruits and vegetables) may increase risk of AML (MLL+) infant leukemia by inducing DNA cleavage and $t(4 ; 11)$ translocation.

Investigate the anti-cancer effect of REH ALL cell line. Cell viability, gene curcumin on a human ALL cell line. (activation of NF- $\mathrm{KB}$ and
- Curcumin enhanced caspase-3 activation and downregulated NF- $\mathrm{kB}$ activation - Curcumin prevents DNA oxidation by decreasing in DNA adduct formation. 


\section{The Role of Nutrition in the Developing Immune System and the Management of Preleukemic and Leukemic Clones}

To date, the etiology of leukemia has been primarily attributed to an interplay between genetic mutations and the response of the developing immune system to early-life infections. This conclusion stems from a hypothesis first raised by Greaves [100]. In 1988, Greaves first addressed that early-life infection was a crucial factor in the immune response and the immune cell network [100]. Lack of infectious exposure neonatally and in infancy, for instance, when isolated in a more affluent "hygienic" environment, might fail to program the immune system. Delayed exposure to common infections, along with abnormal immune function, might result in childhood leukemia [101]. As additional evidence has emerged in recent years, Greaves' hypothesis has been more widely accepted as a cause for leukemia development. Studies after Greaves that sought to consolidate his hypothesis looked into immune modulation of preleukemia by focusing on preleukemic children's vaccination history, daycare attendance, common early-life infections, and the presence of autoimmune responses such as allergies. A nation-wide vaccine trial compared the early and late phase with the haemophilus influenzae type B vaccine in 11,000 children born in Finland and found early vaccinations may reduce the risk of childhood leukemia [102]. A French case-control study also supported Greaves' hypothesis by identifying inverse associations between childhood leukemia and day-care attendance, early common infections, and breast-feeding periods [103]. Evidence of a protective role of early-life infection exposure was identified in the Northern California Childhood Leukemia Study which enrolled 699 ALL cases and 977 controls. In their study, ear infection before 6 months was associated with a reduced risk of ALL among Hispanic and non-Hispanic populations [104]. Compared to early-life (first 3 months) infection, late phase (6-9 months) exposures to influenza and respiratory syncytial virus (RSV) were strongly associated with incidence of pediatric ALL [105]. By the same token, allergies have been found to lower the risk of childhood leukemia, although they are not related to infections [106,107]. Animal evidence also supports Greaves' hypothesis. Immunostimulatory DNA-containing unmethylated CpG dinucleotides (CpG ODN) can mimic the "danger" signal from infections provided to the immune system. In vivo treatment with $\mathrm{CpG}$ ODN can enhance the innate immune activity, and thus induce durable alleviation and immune-mediated protection in ALL [108].

While normal early-life infections can reduce the risk of leukemia, more serious clinically diagnosed infections can be indicators for abnormal immune function, which can increase the probability of developing the disease. More episodes of medically diagnosed infections were associated with increased incidences of both childhood ALL and AML [109]. A matched case-control study enrolling 1600 cases ALL and 16,000 controls aged 2-14 years from Canada demonstrated that having more infections ( $>2$ infections/year) or an infection between the age of 1-1.5 years may increase the risk of developing childhood ALL [110]. In conclusion, Greaves' hypothesis and the additional confirmatory studies show that early-life infections can "educate" the developing immune system and correct its course before developing complete childhood leukemia. However, this conclusion assumes an immune system that is robust in tackling infections.

Prenatal and postnatal development of the immune system plays a pivotal role in determining the risk of acquiring childhood leukemia. Importantly, the balance of macronutrients and micronutrients has demonstrable impacts on systemic inflammation and immunity [111,112]. Obesity, for example, is linked to chronic inflammation through a variety of mechanisms. Excessive free fatty acids released from the adipose tissue promote inflammation by binding to the Toll-like receptors, a family of transmembrane proteins that are responsible for controlling inflammatory and immunological responses, consequently increasing the expression of multiple pro-inflammatory cytokines [113-115]. These cytokines are essential for tumorigenesis, as they stimulate the expression of adhesion molecules on stromal and immune cells, and induce angiogenic factors, chemokines, matrix metalloprotease proteins (MMPs), and reactive oxygen species (ROS) [116,117]. Obesity is also known as a significant driver of macrophage infiltration and the dysregu- 
lation of M1/M2 macrophage balance, which influences many different aspects of tumor progression [118,119].

Micronutrient components, such as vitamin A, vitamin C, and vitamin D, also influence cancer prevention and therapy [120]. Vitamin A and its bioactive metabolite, retinoic acid, regulate immune activity [121]. Retinoic acid can enhance natural killer cell activity, IL-2 secretion, and the CD4+/CD8+ T cell ratio. For these reasons, several experimental studies and clinical trials have examined the essential role of retinoic acid in the treatment of hematological malignancies, such as cutaneous $\mathrm{T}$ cell lymphoma and acute promyelocytic leukemia [122-126]. Vitamin C, a powerful antioxidant, promotes immune defense by regulating various cell functions [127]. A recent experimental study showed that vitamin C could inhibit tumor growth by increasing the cytotoxic activity of adoptively transferred CD8+ T cells [128]. Vitamin C can also elevate the efficacy of immune checkpoint inhibitors to induce a complete response and reduce monotherapy doses [128]. Finally, vitamin D has also been considered to have an anti-proliferation effect in melanoma by strengthening cytotoxic activity and functioning as an immune regulator through the expression of immune checkpoint modulator PDL-1 [129]. While there is much to learn, it is clear that nutrition may have significant beneficial effects on immune activities, including responses to early-life infection and the surveillance of preleukemic and leukemic clones.

\section{Future Perspectives and Applications}

Nutrigenomic studies offer insights into the mechanics of nutrient-gene interactions for preventive strategies, treatment strategies, palliative care, and to improve public health in general [130]. It is evident that nutritional and environmental exposures in-utero greatly influence childhood leukemia incidence [36]. Therefore, adequate nutrition should be promoted early as a preventive lifestyle rather than a cure. Malnutrition and obesity can also affect how the body responds to treatment, and if not managed well, can contribute to relapse. Indeed, studies highlight the need for nutritional interventions during cancer treatment to improve prognosis and quality of life post-treatment [131]. The design of clinically relevant interventions, however, is complicated by diverse variables (genetics, environment, culture, economics, intake amount, metabolic ability, lifestyle) that may heavily influence data interpretation and outcomes [132]. Moreover, changing nutritional signatures during treatment pose an additional challenge that prompts further evaluation [133]. However, the potential benefits associated with nutritional counselling and better follow-up may include the improvement of quality of life and relapse-free survival. Thus, future avenues of research should include multiple omics analysis that study the impact of nutrition on epigenetics (especially DNA damage to the genome), the gut microbiome, and other factors that may influence an individual's dietary preferences or response to treatment [130-132]. For example, a recent study used a big data framework approach to predict outcomes in childhood leukemia patients [134]. Moreover, while additional animal and human studies remain a critical need in the area of nutrition, it may be useful to focus on better structured analyses, possibly incorporating machine learning, to summarize existing associations. However, in the near term, encouraging healthy eating and increasing access to affordable organic and healthy foods, which today are out-of-reach for far too many, has the potential to improve treatment responses and children's health.

\section{Conclusions}

Childhood leukemias have an in-utero origin wherein preleukemic cells exist prenatally. Indeed, the etiology of leukemia is thought to rely on the interactions of transforming mutations occurring in immature immune cells and the developing immune system, which itself is shaped by the balance of macronutrients and micronutrients. Maternal diet and nutrition, therefore, are likely to be essential in the determination of disease predisposition. Consistently, many aspects of the maternal diet associate with a lower risk of developing leukemia, including a balanced maternal diet, folate supplementation, restricted exposure to alcohol, smoking, and caffeine. Similarly, exposures to environmental toxins, both chem- 
ical and radiation, have long-term health effects, including an elevated predisposition to cancer. Moreover, obesity and malnutrition in the affected child associate with high risk of disease, increased treatment-related morbidity, and reduced event-free survival. The molecular mechanisms that account for these adverse events are being uncovered, and include strong connections between micronutrient deficiencies and elevated occurrences of genome instability measured at the cellular level. Tragically, inadequate nutrition is often a result of socio-economic forces, but diet quality improvement may help to reduce the burden of childhood leukemia and the long-term adverse health effects of current treatments.

Author Contributions: Conceptualization, S.W., C.A.M., and N.M.A.; investigation, S.W., C.A.M., and N.M.A.; writing-original draft preparation, S.W. and N.M.A.; writing-review and editing, S.W., C.A.M., and N.M.A.; supervision, C.A.M.; funding acquisition, C.A.M. All authors have read and agreed to the published version of the manuscript.

Funding: This research was funded by Michael Cuccione Foundation through the Better Responses through Avatomics Evidence (BRAvE) Initiative (CAM, NMA), and BCCHR salary award (CAM).

Acknowledgments: The authors acknowledge the support of the Michael Cuccione Foundation.

Conflicts of Interest: The authors declare no conflict of interest.

Methodology: General keywords-maternal nutrition, childhood nutrition, obesity, diet and leukemia incidence, genome stability, immune system, early-life infections, prevalence, risk, progression were searched on PubMed and relevant results were selected for discussion.

\section{Abbreviations}

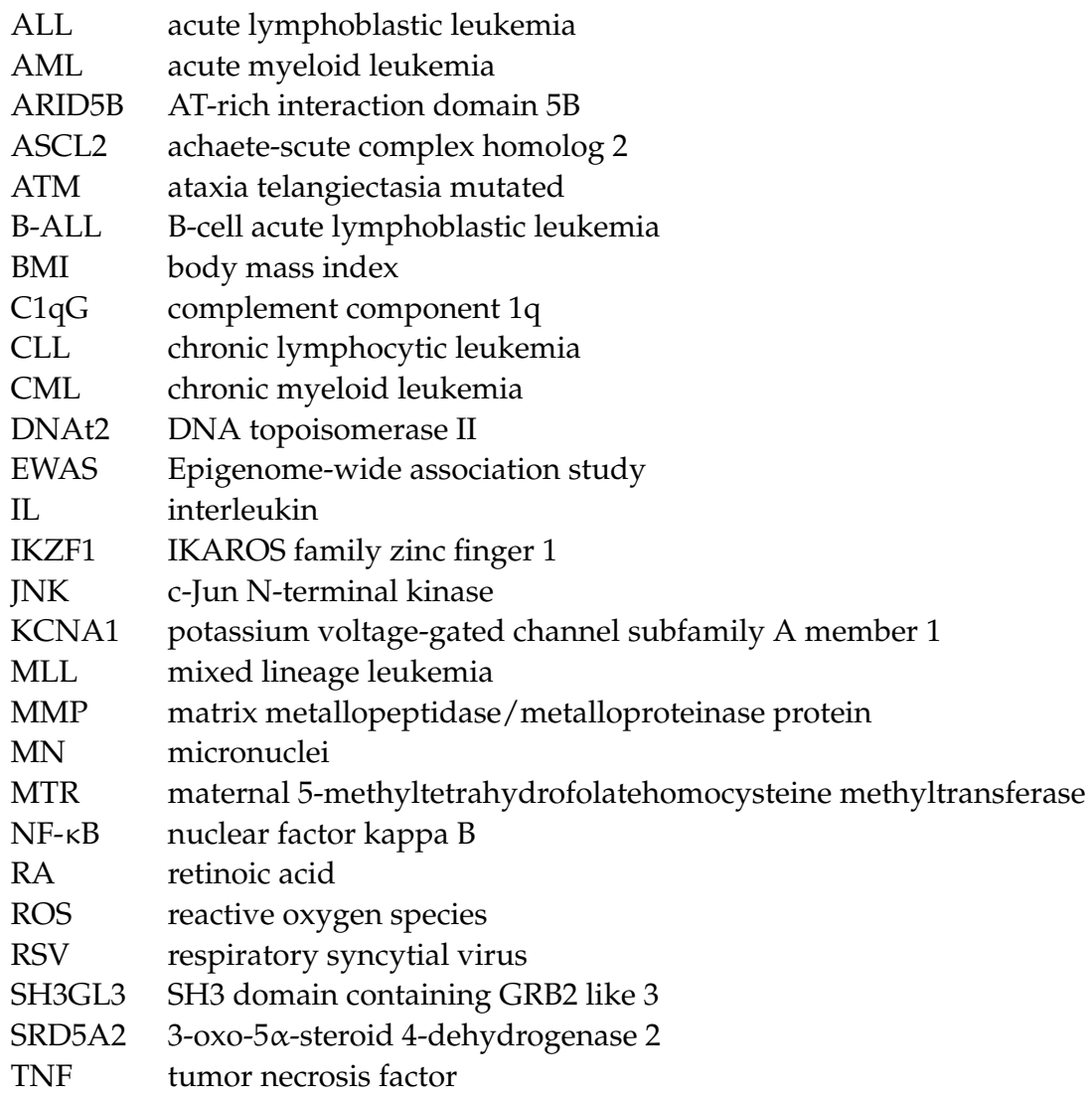




\section{References}

1. Mayne, S.T.; Playdon, M.C.; Rock, C.L. Diet, nutrition, and cancer: Past, present and future. Nat. Rev. Clin. Oncol. 2016, 13, 504-515. [CrossRef] [PubMed]

2. Doll, R.; Peto, R. The causes of cancer: Quantitative estimates of avoidable risks of cancer in the United States today. J. Natl. Cancer Inst. 1981, 66, 1191-1308. [CrossRef] [PubMed]

3. La Vecchia, C.; Muñoz, S.E.; Braga, C.; Fernandez, E.; Decarli, A. Diet diversity and gastric cancer. Int. J. Cancer 1997, 72, 255-257. [CrossRef]

4. Larsson, S.C.; Wolk, A. Meat consumption and risk of colorectal cancer: A meta-analysis of prospective studies. Int. J. Cancer 2006, 119, 2657-2664. [CrossRef]

5. Hursting, S.D.; Perkins, S.N.; Phang, J.M.; Barrett, J.C. Diet and cancer prevention studies in p53-deficient mice. J. Nutr. 2001, 131, 3092S-3094S. [CrossRef] [PubMed]

6. Colby-Graham, M.F.; Chordas, C. The childhood leukemias. J. Pediatr. Nurs. 2003, 18, 87-95. [CrossRef]

7. Filbin, M.; Monje, M. Developmental origins and emerging therapeutic opportunities for childhood cancer. Nat. Med. 2019, 25, 367-376. [CrossRef] [PubMed]

8. Kim, A.S.; Eastmond, D.A.; Preston, R.J. Childhood acute lymphocytic leukemia and perspectives on risk assessment of early-life stage exposures. Mutat. Res. 2006, 613, 138-160. [CrossRef]

9. Greaves, M. A causal mechanism for childhood acute lymphoblastic leukaemia. Nat. Rev. Cancer 2018, 18, 471-484. [CrossRef]

10. Dzierzak, E.; Bigas, A. Blood Development: Hematopoietic Stem Cell Dependence and Independence. Cell Stem Cell 2018, 22, 639-651. [CrossRef]

11. Marshall, G.M.; Carter, D.R.; Cheung, B.B.; Liu, T.; Mateos, M.K.; Meyerowitz, J.G.; Weiss, W.A. The prenatal origins of cancer. Nat. Rev. Cancer 2014, 14, 277-289. [CrossRef] [PubMed]

12. Godfrey, K.M. Maternal regulation of fetal development and health in adult life. Eur. J. Obstet. Gynecol. Reprod. Biol. 1998, 78, 141-150. [CrossRef]

13. Petridou, E.; Ntouvelis, E.; Dessypris, N.; Terzidis, A.; Trichopoulos, D.; The Childhood Hematology-Oncology Group. Maternal diet and acute lymphoblastic leukemia in young children. Cancer Epidemiol. Biomark. Prev. 2005, 14, 1935-1939. [CrossRef] [PubMed]

14. Abiri, B.; Kelishadi, R.; Sadeghi, H.; Azizi-Soleiman, F. Effects of Maternal Diet during Pregnancy on the Risk of Childhood Acute Lymphoblastic Leukemia: A Systematic Review. Nutr. Cancer 2016, 68, 1065-1072. [CrossRef] [PubMed]

15. Kwan, M.L.; Block, G.; Selvin, S.; Month, S.; Buffler, P.A. Food consumption by children and the risk of childhood acute leukemia. Am. J. Epidemiol. 2004, 160, 1098-1107. [CrossRef]

16. Liu, C.Y.; Hsu, Y.H.; Wu, M.T.; Pan, P.C.; Ho, C.K.; Su, L.; Xu, X.; Li, Y.; Christiani, D.C.; Kaohsiung Leukemia Research Group. Cured meat, vegetables, and bean-curd foods in relation to childhood acute leukemia risk: A population based case-control study. BMC Cancer 2009, 9, 15. [CrossRef]

17. Dessypris, N.; Karalexi, M.A.; Ntouvelis, E.; Diamantaras, A.A.; Papadakis, V.; Baka, M.; Hatzipantelis, E.; Kourti, M.; Moschovi, M.; Polychronopoulou, S.; et al. Association of maternal and index child's diet with subsequent leukemia risk: A systematic review and meta analysis. Cancer Epidemiol. 2017, 47, 64-75. [CrossRef]

18. Kwan, M.L.; Jensen, C.D.; Block, G.; Hudes, M.L.; Chu, L.W.; Buffler, P.A. Maternal diet and risk of childhood acute lymphoblastic leukemia. Public Health Rep. 2009, 124, 503-514. [CrossRef]

19. Singer, A.W.; Carmichael, S.L.; Selvin, S.; Fu, C.; Block, G.; Metayer, C. Maternal diet quality before pregnancy and risk of childhood leukaemia. Br. J. Nutr. 2016, 116, 1469-1478. [CrossRef]

20. Metayer, C.; Milne, E.; Dockerty, J.D.; Clavel, J.; Pombo-de-Oliveira, M.S.; Wesseling, C.; Spector, L.G.; Schüz, J.; Petridou, E.; Ezzat, S.; et al. Maternal supplementation with folic acid and other vitamins and risk of leukemia in offspring: A Childhood Leukemia International Consortium study. Epidemiology 2014, 25, 811-822. [CrossRef]

21. Stefanska, B.; Karlic, H.; Varga, F.; Fabianowska-Majewska, K.; Haslberger, A. Epigenetic mechanisms in anti-cancer actions of bioactive food components-the implications in cancer prevention. Br. J. Pharmacol. 2012, 167, 279-297. [CrossRef] [PubMed]

22. MacArthur, A.C.; McBride, M.L.; Spinelli, J.J.; Tamaro, S.; Gallagher, R.P.; Theriault, G. Risk of childhood leukemia associated with parental smoking and alcohol consumption prior to conception and during pregnancy: The cross-Canada childhood leukemia study. Cancer Causes Control. 2008, 19, 283-295. [CrossRef] [PubMed]

23. Karalexi, M.A.; Dessypris, N.; Thomopoulos, T.P.; Ntouvelis, E.; Kantzanou, M.; Diamantaras, A.A.; Moschovi, M.; Baka, M.; Hatzipantelis, E.; Kourti, M.; et al. Parental alcohol consumption and risk of leukemia in the offspring: A systematic review and meta-analysis. Eur. J. Cancer Prev. 2017, 26, 433-441. [CrossRef] [PubMed]

24. Karalexi, M.A.; Dessypris, N.; Clavel, J.; Metayer, C.; Erdmann, F.; Orsi, L.; Kang, A.Y.; Schüz, J.; Bonaventure, A.; Greenop, K.R.; et al. Coffee and tea consumption during pregnancy and risk of childhood acute myeloid leukemia: A Childhood Leukemia International Consortium (CLIC) study. Cancer Epidemiol. 2019, 62, 101581. [CrossRef]

25. Thomopoulos, T.P.; Ntouvelis, E.; Diamantaras, A.A.; Tzanoudaki, M.; Baka, M.; Hatzipantelis, E.; Kourti, M.; Polychronopoulou, S.; Sidi, V.; Stiakaki, E.; et al. Maternal and childhood consumption of coffee, tea and cola beverages in association with childhood leukemia: A meta-analysis. Cancer Epidemiol. 2015, 39, 1047-1059. [CrossRef]

26. Sarkaria, J.N.; Busby, E.C.; Tibbetts, R.S.; Roos, P.; Taya, Y.; Karnitz, L.M.; Abraham, R.T. Inhibition of ATM and ATR kinase activities by the radiosensitizing agent, caffeine. Cancer Res. 1999, 59, 4375-4382. 
27. Carvalho, H.; Ortolan, T.G.; dePaula, T.; Leite, R.A.; Weinlich, R.; Amarante-Mendes, G.P.; Menck, C.F. Sustained activation of p53 in confluent nucleotide excision repair-deficient cells resistant to ultraviolet-induced apoptosis. DNA Repair 2008, 7, $922-931$. [CrossRef]

28. Deweese, J.E.; Osheroff, N. The DNA cleavage reaction of topoisomerase II: Wolf in sheep's clothing. Nucleic Acids Res. 2009, 37, 738-748. [CrossRef]

29. Ross, J.A.; Potter, J.D.; Reaman, G.H.; Pendergrass, T.W.; Robison, L.L. Maternal exposure to potential inhibitors of DNA topoisomerase II and infant leukemia (United States): A report from the Children's Cancer Group. Cancer Causes Control. 1996, 7, 581-590. [CrossRef]

30. Fucic, A.; Guszak, V.; Mantovani, A. Transplacental exposure to environmental carcinogens: Association with childhood cancer risks and the role of modulating factors. Reprod. Toxicol. 2017, 72, 182-190. [CrossRef]

31. Amitay, E.L.; Keinan-Boker, L. Breastfeeding and Childhood Leukemia Incidence: A Meta-analysis and Systematic Review. JAMA Pediatr. 2015, 169, e151025. [CrossRef] [PubMed]

32. Molès, J.P.; Tuaillon, E.; Kankasa, C.; Bedin, A.S.; Nagot, N.; Marchant, A.; McDermid, J.M.; Van de Perre, P. Breastmilk cell trafficking induces microchimerism-mediated immune system maturation in the infant. Pediatr. Allergy Immunol. 2018, 29, 133-143. [CrossRef] [PubMed]

33. Kumbhare, S.V.; Patangia, D.V.V.; Patil, R.H.; Shouche, Y.S.; Patil, N.P. Factors influencing the gut microbiome in children: From infancy to childhood. J. Biosci. 2019, 44. [CrossRef]

34. Petrick, L.M.; Schiffman, C.; Edmands, W.M.B.; Yano, Y.; Perttula, K.; Whitehead, T.; Metayer, C.; Wheelock, C.E.; Arora, M.; Grigoryan, H.; et al. Metabolomics of neonatal blood spots reveal distinct phenotypes of pediatric acute lymphoblastic leukemia and potential effects of early-life nutrition. Cancer Lett. 2019, 452, 71-78. [CrossRef] [PubMed]

35. Pelkonen, O.; Terron, A.; Hernandez, A.F.; Menendez, P.; Bennekou, S.H. Chemical exposure and infant leukaemia: Development of an adverse outcome pathway (AOP) for aetiology and risk assessment research. Arch. Toxicol. 2017, 91, 2763-2780. [CrossRef]

36. Heindel, J.J.; Skalla, L.A.; Joubert, B.R.; Dilworth, C.H.; Gray, K.A. Review of developmental origins of health and disease publications in environmental epidemiology. Reprod. Toxicol. 2017, 68, 34-48. [CrossRef]

37. Patel, D.M.; Jones, R.R.; Booth, B.J.; Olsson, A.C.; Kromhout, H.; Straif, K.; Vermeulen, R.; Tikellis, G.; Paltiel, O.; Golding, J.; et al. Parental occupational exposure to pesticides, animals and organic dust and risk of childhood leukemia and central nervous system tumors: Findings from the International Childhood Cancer Cohort Consortium (I4C). Int. J. Cancer 2020, 146, $943-952$. [CrossRef]

38. Leuraud, K.; Richardson, D.B.; Cardis, E.; Daniels, R.D.; Gillies, M.; O’Hagan, J.A.; Hamra, G.B.; Haylock, R.; Laurier, D.; Moissonnier, M.; et al. Ionising radiation and risk of death from leukaemia and lymphoma in radiation-monitored workers (INWORKS): An international cohort study. Lancet Haematol. 2015, 2, e276-e281. [CrossRef]

39. Kendall, G.M.; Little, M.P.; Wakeford, R.; Bunch, K.J.; Miles, J.C.; Vincent, T.J.; Meara, J.R.; Murphy, M.F. A record-based case-control study of natural background radiation and the incidence of childhood leukaemia and other cancers in Great Britain during 1980-2006. Leukemia 2013, 27, 3-9. [CrossRef]

40. Berrington de Gonzalez, A.; Salotti, J.A.; McHugh, K.; Little, M.P.; Harbron, R.W.; Lee, C.; Ntowe, E.; Braganza, M.Z.; Parker, L.; Rajaraman, P.; et al. Relationship between paediatric CT scans and subsequent risk of leukaemia and brain tumours: Assessment of the impact of underlying conditions. Br. J. Cancer 2016, 114, 388-394. [CrossRef]

41. Richardson, D.; Sugiyama, H.; Nishi, N.; Sakata, R.; Shimizu, Y.; Grant, E.J.; Soda, M.; Hsu, W.L.; Suyama, A.; Kodama, K.; et al. Ionizing radiation and leukemia mortality among Japanese Atomic Bomb Survivors, 1950-2000. Radiat. Res. 2009, 172, 368-382. [CrossRef] [PubMed]

42. Shao, L.; Luo, Y.; Zhou, D. Hematopoietic stem cell injury induced by ionizing radiation. Antioxid. Redox Signal 2014, 20, 1447-1462. [CrossRef] [PubMed]

43. Morishima, H.O.; Pedersen, H.; Finster, M. The influence of maternal psychological stress on the fetus. Am. J. Obstet. Gynecol. 1978, 131, 286-290. [CrossRef]

44. Lobato-Mendizábal, E.; López-Martínez, B.; Ruiz-Argüelles, G.J. A critical review of the prognostic value of the nutritional status at diagnosis in the outcome of therapy of children with acute lymphoblastic leukemia. Rev. Invest. Clin. 2003, 55, 31-35. [PubMed]

45. Pribnow, A.K.; Ortiz, R.; Báez, L.F.; Mendieta, L.; Luna-Fineman, S. Effects of malnutrition on treatment-related morbidity and survival of children with cancer in Nicaragua. Pediatr. Blood Cancer 2017, 64. [CrossRef]

46. Loeffen, E.A.; Brinksma, A.; Miedema, K.G.; de Bock, G.H.; Tissing, W.J. Clinical implications of malnutrition in childhood cancer patients-infections and mortality. Support. Care Cancer 2015, 23, 143-150. [CrossRef]

47. Aarnivala, H.; Pokka, T.; Soininen, R.; Möttönen, M.; Harila-Saari, A.; Niinimäki, R. Trends in age- and sex-adjusted body mass index and the prevalence of malnutrition in children with cancer over 42 months after diagnosis: A single-center cohort study. Eur. J. Pediatr. 2020, 179, 91-98. [CrossRef]

48. Barr, R.D.; Gomez-Almaguer, D.; Jaime-Perez, J.C.; Ruiz-Argüelles, G.J. Importance of Nutrition in the Treatment of Leukemia in Children and Adolescents. Arch. Med. Res. 2016, 47, 585-592. [CrossRef]

49. World Health Organization. Global Health Risks: Mortality and Burden of Disease Attributable to Selected Major Risks; World Health Organization: Geneva, Switzerland, 2009; 62p. 
50. Ladas, E.J.; Orjuela, M.; Stevenson, K.; Cole, P.D.; Lin, M.; Athale, U.H.; Clavell, L.A.; Leclerc, J.M.; Laverdiere, C.; Michon, B.; et al. Fluctuations in dietary intake during treatment for childhood leukemia: A report from the DALLT cohort. Clin. Nutr. 2019, 38, 2866-2874. [CrossRef]

51. Edlow, A.G.; Hui, L.; Wick, H.C.; Fried, I.; Bianchi, D.W. Assessing the fetal effects of maternal obesity via transcriptomic analysis of cord blood: A prospective case-control study. BJOG Int. J. Obstet. Gynaecol. 2016, 123, 180-189. [CrossRef]

52. Ghosh, T.; Richardson, M.; Gordon, P.M.; Ryder, J.R.; Spector, L.G.; Turcotte, L.M. Body mass index associated with childhood and adolescent high-risk B-cell acute lymphoblastic leukemia risk: A Children's Oncology Group report. Cancer Med. 2020. [CrossRef] [PubMed]

53. Yun, J.P.; Behan, J.W.; Heisterkamp, N.; Butturini, A.; Klemm, L.; Ji, L.; Groffen, J.; Müschen, M.; Mittelman, S.D. Diet-induced obesity accelerates acute lymphoblastic leukemia progression in two murine models. Cancer Prev. Res. 2010, 3, 1259-1264. [CrossRef] [PubMed]

54. Arends, J.; Bachmann, P.; Baracos, V.; Barthelemy, N.; Bertz, H.; Bozzetti, F.; Fearon, K.; Hütterer, E.; Isenring, E.; Kaasa, S.; et al. ESPEN guidelines on nutrition in cancer patients. Clin. Nutr. 2017, 36, 11-48. [CrossRef] [PubMed]

55. de Las Peñas, R.; Majem, M.; Perez-Altozano, J.; Virizuela, J.A.; Cancer, E.; Diz, P.; Donnay, O.; Hurtado, A.; Jimenez-Fonseca, P.; Ocon, M.J. SEOM clinical guidelines on nutrition in cancer patients (2018). Clin. Transl. Oncol. 2019, 21, 87-93. [CrossRef]

56. Zhang, F.F.; Liu, S.; Chung, M.; Kelly, M.J. Growth patterns during and after treatment in patients with pediatric ALL: A meta-analysis. Pediatr. Blood Cancer 2015, 62, 1452-1460. [CrossRef]

57. Han, Y.; Zhang, F.; Wang, J.; Zhu, Y.; Dai, J.; Bu, Y.; Yang, Q.; Xiao, Y.; Sun, X. Application of Glutamine-enriched nutrition therapy in childhood acute lymphoblastic leukemia. Nutr. J. 2016, 15, 65. [CrossRef]

58. Bindels, L.B.; Beck, R.; Schakman, O.; Martin, J.C.; De Backer, F.; Sohet, F.M.; Dewulf, E.M.; Pachikian, B.D.; Neyrinck, A.M.; Thissen, J.P.; et al. Restoring specific lactobacilli levels decreases inflammation and muscle atrophy markers in an acute leukemia mouse model. PLoS ONE 2012, 7, e37971. [CrossRef]

59. Ladas, E.J.; Blonquist, T.M.; Puligandla, M.; Orjuela, M.; Stevenson, K.; Cole, P.D.; Athale, U.H.; Clavell, L.A.; Leclerc, J.M.; Laverdiere, C.; et al. Protective Effects of Dietary Intake of Antioxidants and Treatment-Related Toxicity in Childhood Leukemia: A Report From the DALLT Cohort. J. Clin. Oncol. 2020, 38, 2151-2159. [CrossRef]

60. Bhattacharya, S.; Verma, N.; Kumar, A. Prevalence of vitamin D deficiency in childhood acute lymphoblastic leukemia and its association with adverse outcomes during induction phase of treatment. Nutr. Cancer 2020, 72, 1321-1325. [CrossRef]

61. Raber, M.; Wu, J.; Donnella, H.; Knouse, P.; Pise, M.; Munsell, M.; Liu, D.; Chandra, J. Cellular Oxidative Stress in Pediatric Leukemia and Lymphoma Patients Undergoing Treatment Is Associated with Protein Consumption. Nutrients 2019, 12, 75. [CrossRef]

62. Rubio-Patiño, C.; Bossowski, J.P.; De Donatis, G.M.; Mondragón, L.; Villa, E.; Aira, L.E.; Chiche, J.; Mhaidly, R.; Lebeaupin, C.; Marchetti, S.; et al. Low-Protein Diet Induces IRE1 $\alpha$-Dependent Anticancer Immunosurveillance. Cell Metab. 2018, 27, 828-842.e827. [CrossRef] [PubMed]

63. Fenech, M. The Genome Health Clinic and Genome Health Nutrigenomics concepts: Diagnosis and nutritional treatment of genome and epigenome damage on an individual basis. Mutagenesis 2005, 20, 255-269. [CrossRef] [PubMed]

64. Ames, B.N. DNA damage from micronutrient deficiencies is likely to be a major cause of cancer. Mutat. Res. 2001, 475, 7-20. [CrossRef]

65. Halliwell, B. Vitamin C and genomic stability. Mutat. Res. 2001, 475, 29-35. [CrossRef]

66. Hartwig, A. Role of magnesium in genomic stability. Mutat. Res. 2001, 475, 113-121. [CrossRef]

67. Prá, D.; Bortoluzzi, A.; Müller, L.L.; Hermes, L.; Horta, J.A.; Maluf, S.W.; Henriques, J.A.; Fenech, M.; Franke, S.I. Iron intake, red cell indicators of iron status, and DNA damage in young subjects. Nutrition 2011, 27, 293-297. [CrossRef]

68. Troadec, M.B.; Loréal, O.; Brissot, P. The interaction of iron and the genome: For better and for worse. Mutat. Res. 2017, 774, 25-32. [CrossRef]

69. Zhang, C. Essential functions of iron-requiring proteins in DNA replication, repair and cell cycle control. Protein Cell 2014, 5, 750-760. [CrossRef]

70. Jozwiakowski, S.K.; Kummer, S.; Gari, K. Human DNA polymerase delta requires an iron-sulfur cluster for high-fidelity DNA synthesis. Life Sci. Alliance 2019, 2. [CrossRef]

71. Prá, D.; Franke, S.I.; Henriques, J.A.; Fenech, M. Iron and genome stability: An update. Mutat. Res. 2012, 733, 92-99. [CrossRef]

72. Prá, D.; Franke, S.I.; Giulian, R.; Yoneama, M.L.; Dias, J.F.; Erdtmann, B.; Henriques, J.A. Genotoxicity and mutagenicity of iron and copper in mice. Biometals 2008, 21, 289-297. [CrossRef] [PubMed]

73. Martínez de Victoria, E. Calcium, essential for health. Nutr. Hosp. 2016, 33, 341. [CrossRef] [PubMed]

74. O'Callaghan, N.J.; Bull, C.; Fenech, M. Elevated plasma magnesium and calcium may be associated with shorter telomeres in older South Australian women. J. Nutr. Health Aging 2014, 18, 131-136. [CrossRef] [PubMed]

75. Inukai, T.; Hirose, K.; Inaba, T.; Kurosawa, H.; Hama, A.; Inada, H.; Chin, M.; Nagatoshi, Y.; Ohtsuka, Y.; Oda, M.; et al. Hypercalcemia in childhood acute lymphoblastic leukemia: Frequent implication of parathyroid hormone-related peptide and E2A-HLF from translocation 17;19. Leukemia 2007, 21, 288-296. [CrossRef]

76. Milne, E.; Greenop, K.R.; Ramankutty, P.; Miller, M.; de Klerk, N.H.; Armstrong, B.K.; Almond, T.; O'Callaghan, N.J.; Fenech, M. Blood micronutrients and DNA damage in children. Mol. Nutr. Food Res. 2015, 59, 2057-2065. [CrossRef] 
77. Ladeira, C.; Carolino, E.; Gomes, M.C.; Brito, M. Role of Macronutrients and Micronutrients in DNA Damage: Results from a Food Frequency Questionnaire. Nutr. Metab. Insights 2017, 10. [CrossRef]

78. Cheng, W.H. Impact of inorganic nutrients on maintenance of genomic stability. Environ. Mol. Mutagen. 2009, 50, 349-360. [CrossRef]

79. Sharif, R.; Thomas, P.; Zalewski, P.; Graham, R.D.; Fenech, M. The effect of zinc sulphate and zinc carnosine on genome stability and cytotoxicity in the WIL2-NS human lymphoblastoid cell line. Mutat. Res. 2011, 720, 22-33. [CrossRef]

80. MacDonald, R.S. The role of zinc in growth and cell proliferation. J. Nutr. 2000, 130, 1500S-1508S. [CrossRef]

81. Padula, G.; Ponzinibbio, M.V.; Gambaro, R.C.; Seoane, A.I. Genomic instability related to zinc deficiency and excess in an in vitro model: Is the upper estimate of the physiological requirements recommended for children safe? Vitro Cell Dev. Biol. Anim. 2017, 53, 586-592. [CrossRef]

82. Darbre, P.D.; Mannello, F.; Exley, C. Aluminium and breast cancer: Sources of exposure, tissue measurements and mechanisms of toxicological actions on breast biology. J. Inorg. Biochem. 2013, 128, 257-261. [CrossRef] [PubMed]

83. Lee, D.H.; O'Connor, T.R.; Pfeifer, G.P. Oxidative DNA damage induced by copper and hydrogen peroxide promotes CG->TT tandem mutations at methylated CpG dinucleotides in nucleotide excision repair-deficient cells. Nucleic Acids Res. 2002, 30, 3566-3573. [CrossRef] [PubMed]

84. Fenech, M.; Baghurst, P.; Luderer, W.; Turner, J.; Record, S.; Ceppi, M.; Bonassi, S. Low intake of calcium, folate, nicotinic acid, vitamin E, retinol, beta-carotene and high intake of pantothenic acid, biotin and riboflavin are significantly associated with increased genome instability-results from a dietary intake and micronucleus index survey in South Australia. Carcinogenesis 2005, 26, 991-999. [CrossRef] [PubMed]

85. Xiao, R.; Su, Y.; Simmen, R.C.; Simmen, F.A. Dietary soy protein inhibits DNA damage and cell survival of colon epithelial cells through attenuated expression of fatty acid synthase. Am. J. Physiol. Gastrointest Liver Physiol. 2008, 294, G868-G876. [CrossRef]

86. Toden, S.; Bird, A.R.; Topping, D.L.; Conlon, M.A. Resistant starch prevents colonic DNA damage induced by high dietary cooked red meat or casein in rats. Cancer Biol. Ther. 2006, 5, 267-272. [CrossRef]

87. American Institute for Cancer Research. Dietary Fat and Cancer: Genetic and Molecular Interactions; Plenum Press: New York, NY, USA, 1997; 252p.

88. Sakai, C.; Ishida, M.; Ohba, H.; Yamashita, H.; Uchida, H.; Yoshizumi, M.; Ishida, T. Fish oil omega-3 polyunsaturated fatty acids attenuate oxidative stress-induced DNA damage in vascular endothelial cells. PLoS ONE 2017, 12, e0187934. [CrossRef]

89. Setayesh, T.; Nersesyan, A.; Mišík, M.; Noorizadeh, R.; Haslinger, E.; Javaheri, T.; Lang, E.; Grusch, M.; Huber, W.; Haslberger, A.; et al. Gallic acid, a common dietary phenolic protects against high fat diet induced DNA damage. Eur. J. Nutr. 2019, 58, 2315-2326. [CrossRef]

90. Daugherity, E.K.; Balmus, G.; Al Saei, A.; Moore, E.S.; Abi Abdallah, D.; Rogers, A.B.; Weiss, R.S.; Maurer, K.J. The DNA damage checkpoint protein ATM promotes hepatocellular apoptosis and fibrosis in a mouse model of non-alcoholic fatty liver disease. Cell Cycle 2012, 11, 1918-1928. [CrossRef]

91. Stacy, S.L.; Buchanich, J.M.; Ma, Z.Q.; Mair, C.; Robertson, L.; Sharma, R.K.; Talbott, E.O.; Yuan, J.M. Maternal Obesity, Birth Size, and Risk of Childhood Cancer Development. Am. J. Epidemiol. 2019, 188, 1503-1511. [CrossRef]

92. Contreras, Z.A.; Ritz, B.; Virk, J.; Cockburn, M.; Heck, J.E. Maternal pre-pregnancy and gestational diabetes, obesity, gestational weight gain, and risk of cancer in young children: A population-based study in California. Cancer Causes Control. 2016, 27, 1273-1285. [CrossRef]

93. Timms, J.A.; Relton, C.L.; Sharp, G.C.; Rankin, J.; Strathdee, G.; McKay, J.A. Exploring a potential mechanistic role of DNA methylation in the relationship between in utero and post-natal environmental exposures and risk of childhood acute lymphoblastic leukaemia. Int. J. Cancer 2019, 145, 2933-2943. [CrossRef]

94. Schraw, J.M.; Yiu, T.T.; Lupo, P.J.; Tsavachidis, S.; Rau, R.; Bondy, M.L.; Rabin, K.R.; Shen, L.; Scheurer, M.E. Maternal folate genes and aberrant DNA hypermethylation in pediatric acute lymphoblastic leukemia. PLoS ONE 2018, 13, e0197408. [CrossRef]

95. Evans, T.J.; Milne, E.; Anderson, D.; de Klerk, N.H.; Jamieson, S.E.; Talseth-Palmer, B.A.; Bowden, N.A.; Holliday, E.G.; Rudant, J.; Orsi, L.; et al. Confirmation of childhood acute lymphoblastic leukemia variants, ARID5B and IKZF1, and interaction with parental environmental exposures. PLoS ONE 2014, 9, e110255. [CrossRef] [PubMed]

96. Løhmann, D.J.A.; Asdahl, P.H.; Abrahamsson, J.; Ha, S.Y.; Jónsson, Ó.; Kaspers, G.J.L.; Koskenvuo, M.; Lausen, B.; De Moerloose, B.; Palle, J.; et al. Associations between pretherapeutic body mass index, outcome, and cytogenetic abnormalities in pediatric acute myeloid leukemia. Cancer Med. 2019, 8, 6634-6643. [CrossRef]

97. Potter, C.; Moorman, A.V.; Relton, C.L.; Ford, D.; Mathers, J.C.; Strathdee, G.; McKay, J.A. Maternal Red Blood Cell Folate and Infant Vitamin B. Mol. Nutr. Food Res. 2018, 62, e1800411. [CrossRef] [PubMed]

98. Spector, L.G.; Xie, Y.; Robison, L.L.; Heerema, N.A.; Hilden, J.M.; Lange, B.; Felix, C.A.; Davies, S.M.; Slavin, J.; Potter, J.D.; et al. Maternal diet and infant leukemia: The DNA topoisomerase II inhibitor hypothesis: A report from the children's oncology group. Cancer Epidemiol. Biomark. Prev. 2005, 14, 651-655. [CrossRef] [PubMed]

99. Pimentel-Gutiérrez, H.J.; Bobadilla-Morales, L.; Barba-Barba, C.C.; Ortega-De-La-Torre, C.; Sánchez-Zubieta, F.A.; Corona-Rivera, J.R.; González-Quezada, B.A.; Armendáriz-Borunda, J.S.; Silva-Cruz, R.; Corona-Rivera, A. Curcumin potentiates the effect of chemotherapy against acute lymphoblastic leukemia cells via downregulation of NF-kB. Oncol. Lett. 2016, 12, 4117-4124. [CrossRef] [PubMed]

100. Greaves, M.F. Speculations on the cause of childhood acute lymphoblastic leukemia. Leukemia 1988, 2, $120-125$. 
101. Greaves, M. Infection, immune responses and the aetiology of childhood leukaemia. Nat. Rev. Cancer 2006, 6, 193-203. [CrossRef]

102. Auvinen, A.; Hakulinen, T.; Groves, F. Haemophilus influenzae type B vaccination and risk of childhood leukaemia in a vaccine trial in Finland. Br. J. Cancer 2000, 83, 956-958. [CrossRef]

103. Perrillat, F.; Clavel, J.; Auclerc, M.F.; Baruchel, A.; Leverger, G.; Nelken, B.; Philippe, N.; Schaison, G.; Sommelet, D.; Vilmer, E.; et al. Day-care, early common infections and childhood acute leukaemia: A multicentre French case-control study. Br. J. Cancer 2002, 86, 1064-1069. [CrossRef]

104. Urayama, K.Y.; Ma, X.; Selvin, S.; Metayer, C.; Chokkalingam, A.P.; Wiemels, J.L.; Does, M.; Chang, J.; Wong, A.; Trachtenberg, E.; et al. Early life exposure to infections and risk of childhood acute lymphoblastic leukemia. Int. J. Cancer 2011, 128, 1632-1643. [CrossRef]

105. Marcotte, E.L.; Ritz, B.; Cockburn, M.; Yu, F.; Heck, J.E. Exposure to infections and risk of leukemia in young children. Cancer Epidemiol. Biomark. Prev. 2014, 23, 1195-1203. [CrossRef]

106. Spector, L.; Groves, F.; DeStefano, F.; Liff, J.; Klein, M.; Mullooly, J.; Black, S.; Shinefield, H.; Ward, J.; Marcy, M.; et al. Medically recorded allergies and the risk of childhood acute lymphoblastic leukaemia. Eur. J. Cancer 2004, 40, 579-584. [CrossRef]

107. Rosenbaum, P.F.; Buck, G.M.; Brecher, M.L. Allergy and infectious disease histories and the risk of childhood acute lymphoblastic leukaemia. Paediatr. Perinat. Epidemiol. 2005, 19, 152-164. [CrossRef]

108. Seif, A.E.; Barrett, D.M.; Milone, M.; Brown, V.I.; Grupp, S.A.; Reid, G.S. Long-term protection from syngeneic acute lymphoblastic leukemia by CpG ODN-mediated stimulation of innate and adaptive immune responses. Blood 2009, 114, 2459-2466. [CrossRef]

109. Chang, J.S.; Tsai, C.R.; Tsai, Y.W.; Wiemels, J.L. Medically diagnosed infections and risk of childhood leukaemia: A populationbased case-control study. Int. J. Epidemiol. 2012, 41, 1050-1059. [CrossRef]

110. Hwee, J.; Sutradhar, R.; Kwong, J.C.; Sung, L.; Cheng, S.; Pole, J.D. Infections and the development of childhood acute lymphoblastic leukemia: A population-based study. Eur. J. Cancer Prev. 2020, 29, 538-545. [CrossRef]

111. Dunn, G.P.; Koebel, C.M.; Schreiber, R.D. Interferons, immunity and cancer immunoediting. Nat. Rev. Immunol. 2006, 6, 836-848. [CrossRef]

112. Liu, L.; Nishihara, R.; Qian, Z.R.; Tabung, F.K.; Nevo, D.; Zhang, X.; Song, M.; Cao, Y.; Mima, K.; Masugi, Y.; et al. Association Between Inflammatory Diet Pattern and Risk of Colorectal Carcinoma Subtypes Classified by Immune Responses to Tumor. Gastroenterology 2017, 153, 1517-1530.e1514. [CrossRef]

113. Weisberg, S.P.; McCann, D.; Desai, M.; Rosenbaum, M.; Leibel, R.L.; Ferrante, A.W. Obesity is associated with macrophage accumulation in adipose tissue. J. Clin. Investig. 2003, 112, 1796-1808. [CrossRef] [PubMed]

114. Rogero, M.M.; Calder, P.C. Obesity, Inflammation, Toll-Like Receptor 4 and Fatty Acids. Nutrients 2018, 10, 432. [CrossRef] [PubMed]

115. Font-Burgada, J.; Sun, B.; Karin, M. Obesity and Cancer: The Oil that Feeds the Flame. Cell Metab. 2016, 23, 48-62. [CrossRef] [PubMed]

116. Lin, W.W.; Karin, M. A cytokine-mediated link between innate immunity, inflammation, and cancer. J. Clin. Investig. 2007, 117, 1175-1183. [CrossRef] [PubMed]

117. Korneev, K.V.; Atretkhany, K.N.; Drutskaya, M.S.; Grivennikov, S.I.; Kuprash, D.V.; Nedospasov, S.A. TLR-signaling and proinflammatory cytokines as drivers of tumorigenesis. Cytokine 2017, 89, 127-135. [CrossRef]

118. Shapouri-Moghaddam, A.; Mohammadian, S.; Vazini, H.; Taghadosi, M.; Esmaeili, S.A.; Mardani, F.; Seifi, B.; Mohammadi, A.; Afshari, J.T.; Sahebkar, A. Macrophage plasticity, polarization, and function in health and disease. J. Cell. Physiol. 2018, 233, 6425-6440. [CrossRef]

119. Qian, B.Z.; Pollard, J.W. Macrophage diversity enhances tumor progression and metastasis. Cell 2010, 141, 39-51. [CrossRef]

120. Irimie, A.I.; Braicu, C.; Pasca, S.; Magdo, L.; Gulei, D.; Cojocneanu, R.; Ciocan, C.; Olariu, A.; Coza, O.; Berindan-Neagoe, I. Role of Key Micronutrients from Nutrigenetic and Nutrigenomic Perspectives in Cancer Prevention. Medicina 2019, 55, 283. [CrossRef]

121. Carratù, M.R.; Marasco, C.; Mangialardi, G.; Vacca, A. Retinoids: Novel immunomodulators and tumour-suppressive agents? Br. J. Pharmacol. 2012, 167, 483-492. [CrossRef]

122. Ahmad, S.M.; Haskell, M.J.; Raqib, R.; Stephensen, C.B. Markers of innate immune function are associated with vitamin a stores in men. J. Nutr. 2009, 139, 377-385. [CrossRef]

123. Ertesvag, A.; Engedal, N.; Naderi, S.; Blomhoff, H.K. Retinoic acid stimulates the cell cycle machinery in normal T cells: Involvement of retinoic acid receptor-mediated IL-2 secretion. J. Immunol. 2002, 169, 5555-5563. [CrossRef] [PubMed]

124. Recchia, F.; Saggio, G.; Cesta, A.; Alesse, E.; Gallo, R.; Necozione, S.; Rea, S. Phase II randomized study of interleukin-2 with or without 13-cis retinoic acid as maintenance therapy in patients with advanced cancer responsive to chemotherapy. Anticancer Res. 2005, 25, 3149-3157. [PubMed]

125. Huen, A.O.; Kim, E.J. The Role of Systemic Retinoids in the Treatment of Cutaneous T-Cell Lymphoma. Dermatol. Clin. 2015, 33, 715-729. [CrossRef] [PubMed]

126. Furugaki, K.; Pokorna, K.; Le Pogam, C.; Aoki, M.; Reboul, M.; Bajzik, V.; Krief, P.; Janin, A.; Noguera, M.E.; West, R.; et al. DNA vaccination with all-trans retinoic acid treatment induces long-term survival and elicits specific immune responses requiring CD4+ and CD8+ T-cell activation in an acute promyelocytic leukemia mouse model. Blood 2010, 115, 653-656. [CrossRef]

127. Carr, A.C.; Maggini, S. Vitamin C and Immune Function. Nutrients 2017, 9, 1211. [CrossRef]

128. Magrì, A.; Germano, G.; Lorenzato, A.; Lamba, S.; Chilà, R.; Montone, M.; Amodio, V.; Ceruti, T.; Sassi, F.; Arena, S.; et al. High-dose vitamin C enhances cancer immunotherapy. Sci. Transl. Med. 2020, 12. [CrossRef] 
129. Stucci, L.S.; D’Oronzo, S.; Tucci, M.; Macerollo, A.; Ribero, S.; Spagnolo, F.; Marra, E.; Picasso, V.; Orgiano, L.; Marconcini, R.; et al. Vitamin D in melanoma: Controversies and potential role in combination with immune check-point inhibitors. Cancer Treat. Rev. 2018, 69, 21-28. [CrossRef]

130. Fenech, M.; El-Sohemy, A.; Cahill, L.; Ferguson, L.R.; French, T.A.; Tai, E.S.; Milner, J.; Koh, W.P.; Xie, L.; Zucker, M.; et al. Nutrigenetics and nutrigenomics: Viewpoints on the current status and applications in nutrition research and practice. J. Nutr. Nutr. 2011, 4, 69-89. [CrossRef]

131. Rogers, P.C.; Barr, R.D. The relevance of nutrition to pediatric oncology: A cancer control perspective. Pediatr. Blood Cancer 2020, 67 (Suppl. 3), e28213. [CrossRef]

132. Riscuta, G.; Xi, D.; Pierre-Victor, D.; Starke-Reed, P.; Khalsa, J.; Duffy, L. Diet, Microbiome, and Epigenetics in the Era of Precision Medicine. Methods Mol. Biol. 2018, 1856, 141-156. [CrossRef]

133. Krzyszczyk, P.; Acevedo, A.; Davidoff, E.J.; Timmins, L.M.; Marrero-Berrios, I.; Patel, M.; White, C.; Lowe, C.; Sherba, J.J.; Hartmanshenn, C.; et al. The growing role of precision and personalized medicine for cancer treatment. Technology 2018, 6, 79-100. [CrossRef]

134. Phillips, C.A.; Pollock, B.H. Big Data for Nutrition Research in Pediatric Oncology: Current State and Framework for Advancement. J. Natl. Cancer Inst. Monogr. 2019, 2019, 127-131. [CrossRef] [PubMed] 